\title{
PEMBENTUKAN KARAKTER KERJASAMA MELALUI SEPAKBOLA USIA DINI PADA LIGA INDONESIA JUNIOR SOCCER LEAGUE
}

\author{
Rio Rama Dhoni \\ Juriana dan Ika Novitaria Marani \\ Fakultas Ilmu Keolahragaan Universitas Negeri Jakarta \\ rioramadhoni@gmail.com
}

\begin{abstract}
ABSTRAK
Penelitian ini bertujuan untuk mengetahui sejauhmana pembentukan karakter kerjasama melalui sepakbola usia dini pada liga Indonesia Junior Soccer League. Penelitian ini dilaksanakan pada bulan Maret hingga bulan Mei 2018 yang berlokasi di Jakarta Japanese Club Sports Community Sentul Bogor, Kabupaten Bogor. Metode yang digunakan pada penelitian ini adalah metode survei, yaitu dengan menggunakan kuesioner pembentukan karakter kerjasama. Populasi dalam penelitian ini adalah orang tua atau wali peserta turnamen Indonesia Junior Soccer League yang berjumlah 1000 orang. Teknik pengambilan sampel dalam penelitian ini adalah insidental sampling, yaitu yang dijadikan sampel adalah orang tua atau wali dari peserta liga Indonesia Junior Soccer League yang peneliti temui secara kebetulan sebanyak 368 orang.

Penelitian ini merupakan penelitian deskriptif kuantitatif. Instrumen yang digunakan adalah angket. Instrumen yang telah tersusun tersebut dikonsultasikan kepada ahli, selanjutnya dilakukan uji validitas dengan hasil rtabel 0,254 dan rtotal 0,66 dan reliabilitas sebesar 0,84. Teknik analisis data yang dilakukan adalah analisis deskriptif dengan prosentase.

Hasil penelitian menunjukkan bahwa pembentukan karakter kerjasama melalui sepakbola usia dini pada liga Indonesia Junior Soccer League berada pada kategori rendah atau buruk sebanyak 16 orang $(4,35 \%)$ terhadap pembentukan karakter kerjasama, sebanyak 192 orang $(52,17 \%)$ memiliki pengetahuan yang sedang atau cukup terhadap pembentukan karakter kerjasama, sebanyak 147 orang $(39,95 \%)$ memiliki pengetahuan yang tinggi atau baik terhadap pembentukan karakter kerjasama dan sebanyak 13 orang $(3,53 \%)$ memiliki pengetahuan yang sangat tinggi atau baik sekali terhadap pembentukan karakter kerjasama.
\end{abstract}

\section{Kata kunci: Pembentukan Karakter, Kerjasama, Sepakbola, Usia Dini}

\section{ABSTRACT}

This study aims to find out how far the formation of the character of cooperation through early soccer in the league of Indonesia Junior Soccer League. The research was conducted from March to May 2018 located at Jakarta Japanese Club Sports Community Sentul Bogor, Bogor District. The method used in this research is survey method, that is by using questionnaire forming character of cooperation. The population in this study is the parents or guardians of the participants of the Indonesia Junior Soccer League tournament which amounted to 1000 people. The sampling technique in this research is incidental sampling, which is taken as sample is the parent or guardian of the Indonesian league participants Junior Soccer League who researchers meet by chance as much as 368 people.

This research is quantitative descriptive. The instrument used is a questionnaire. Instrument that has been arranged was consulted to the expert, then tested the validity with the result 
rtabel 0,254 and rtotal 0,66 and reliability equal to 0,84. Data analysis technique is descriptive analysis with percentage.

The results showed that the formation of the character of cooperation through early soccer in the league Indonesia Junior Soccer League is in the category of low or bad as many as 16 people (4.35\%) on the formation of cooperation character, as many as 192 people (52.17\%) have knowledge of being or enough to form the character of cooperation, as many as 147 people (39.95\%) have a high knowledge or good on the formation of character cooperation and as many as 13 people (3.53\%) have a very high knowledge or excellent on the formation of the character of cooperation

\section{Keywords: Partner Character, Teamplay, Football, Early Age Birds}

\section{PENDAHULUAN}

Bakat merupakan kumpulan sifat-sifat dan kemampuan-kemampuan yang memungkinkan seseorang mencapai prestasi tinggi. Bakat atlet yang satu tidak sama dengan bakat atlet yang lain apabila ditinjau dari tiaptiap komponen kemampuan yang dimiliki, oleh karena itu perlu pendekatan individual sehingga diketahui kelemahan dan kelebihan tiap-tiap atlet. Sepakbola selalu berkembang tiap detik, oleh sebab itu para pembina sepakbola usia muda di Indonesia perlu terus menyesuaikan metode, sistem dan kurikulum latihan di sekolah-sekolah sepakbolanya agar sejalan dengan perkembangan sepakbola modern. Pekerjaan ini tidaklah mudah, sebab pembinaan sepakbola usia muda di Indonesia kini dihadapkan pada berbagai tantangan sosiologis kehidupan modern yang dapat menggangu perkembangan pemain menuju pesepakbola profesional handal.

Dalam situasi perkembangan sepakbola modern tantangan yang mendera pembina sepakbola muda di seluruh sekolah sepakbola yang ada, perlu mengambil peran yang optimal. Sebab SSB kini praktis menjadi satu-satunya tempat bagi anak-anak usia dini yang ingin belajar sepakbola, mustahil rasanya mengharapkan anak-anak usia dini mahir sepakbola tanpa berlatih di SSB. Dalam sepakbola bila pemain muda selalu diajarkan hal salah, maka kesalahan itu akan menjadi permanen dan terus dibawa hingga dewasa, begitupun sebaliknya. Oleh sebab itu, Disni peran pelatih sepakbola usia muda sangat berperan dalam membentuk sifat atau karakter atlet tersebut agar menjadi atlet yang mempunyai mental juara dan siap berkiprah di tingkat profesional. Namun dalam sepakbola, sifat yang terpenting yang harus dimiliki dalam diri atlet adalah jiwa yang kompak atau karakter kerjasama yang berarti tidak egois.

Karakter tidak egois secara harfiah berarti tidak mementingkan diri sendiri. Maknanya bisa meluas dan juga mendalam, seperti Kesan rendah hati, mengalah, dan mementingkan pihak yang lebih butuh, lebih banyak, dan lebih bermanfaat. Tidak egois mengutamakan keselamatan dan ketentraman, tidak berlebihan karenannya dia menyamankan banyak pihak. Orang yang tidak egois nyaris tidak menganggap orang lain sebagai lawan, apalagi musuh yang berbahaya. Orang yang tidak egois akan lebih banyak memiliki teman ketimbang lawan. Dalam permainan sepakbola, pemain yang tidak egois lebih disenangi ketimbang yang egois, sebab pemain dengan karakter tersebut dapat menguntungkan untuk tim, pemain yang tidak egois dapat menahan dirinya jika ada rekan satu tim berada lebih menguntungkan untuk mencetak gol dibandingkan dirinya. Karakter kerja sama tim sangat dibutuhkan untuk memenangkan pertandingan. Karakter kerjasama harus di kembangkan pada atlet usia dini agar kepribadian mereka bisa berkembang sejalan dengan meningkati kemampuan bermain sepakbolanya. Dengan demikian, pemain usia dini tidak menganggap dirinya paling hebat.

Selama ini, pembentukan sepakbola usia dini lebih kepada kemampuan teknis ketimbang membentuk karakter dasar dalam diri pemain. Padahal, usia dini adalah usia 
paling krusial sebab banyak menyerap ilmu dari siapapun. Oleh karena itu, pembentukan karakter kerjasama ini harus benar-benar dibimbing dengan baik. Melalui latihanlatihan, semestinya karakter kerjasama juga bisa terbentuk.

$\begin{array}{rlr}\text { Di } & \text { Indonesia pertandingan untuk } \\ \text { kategori anak usia dini marak }\end{array}$ diselenggarakan. Misalnya pada gelaran Indonesian Junior Socccer League (IJSL) yang tiap tahun selalu menjadi wadah buat anak-anak usia dini. Indonesian junior soccer league ini merupakan salah satu kompetisi usia dini yang bergulir secara berkelanjutan dari tahun ke tahun sejak 2013 hingga sampai saat ini sudah memasuki tahun ke-6 pada 2018 ini. Kompetisi yang diikuti oleh 48 tim dari berbagai SSB ini dibagi menjadi tiga grup yaitu, 16 tim grup merah, 16 tim grup biru dan 16 tim grup putih yang akan bertanding dalam sistem setengah kompetensi. Peringkat 1-4 disetiap grup berhak mengikuti putaran kedua. Kompetisi ini terfokus pada penyaluran dan pembentukan potensi minat dan bakat anak, mengukur dan mengevaluasi kemampuan selama berlatih, menanamkan jiwa sportifitas dan bersosialisasi, memproteksi diri dari pergaulan yang bersifat negatif serta membentuk karakter anak.

Karakter untuk anak usia dini sangatlah penting karena dalam pertandingan anak-anak diharuskan untuk bermain sportif, tidak egois, disiplin dan jujur. Ada tiga fondasi dasar yang menjadikan seseorang bisa mengontrol dirinya untuk menjadi orang baik yaitu tidak egois, jujur dan disiplin. kerjasama dalam pertandingan sangatlah penting sebab sepakbola adalah olahraga tim jadi membutuhkan kerjasama untuk memenangkan sebuah pertandingan, karena tanpa kerjasama mustahil sebuah tim dapat memenangkan pertandingan. Kerjasama dalam bertanding misalnya kita mengoper bola kepada kawan kita yang berada lebih menguntungkan depan gawang dibandingkan dengan kita agar dapat menciptakan goal, tidak memaksakan diri agar kita dapat mencetak gol sendirian. Coakley mendefinisikan kompetisi sebagai sebuah proses sosial yang terjadi ketika penghargaan diberikan kepada orang-orang atas dasar tentang bagaimana penampilan seseorang dibandingkan dengan kinerja orang lain melakukan tugas yang sama atau berpartisipasi pada acara yang sama. Proses lain keberhasilan dapat diukur dan dihargai adalah kerjasama.

Karakter adalah cara berpikir dan berperilaku yang menjadi ciri khas tiap individu untuk hidup bekerja sama, baik dalam lingkup keluarga, masyarakat, bangsa, maupun negara. Selain itu, karakter merupakan tumpuan yang menentukan seberapa besarnya berat seseorang bisa topang. Karena itu, jika pengetahuan mengenai karakter seseorang itu dapat diketahui, maka dapat diketahui pula bagaimana individu tersebut akan bersikap untuk kondisi-kondisi tertentu.

Terdapat pengertian lain tentang karakter yang merupakan suatu watak, tabiat, akhlak atau kepribadian seseorang yang terbentuk dari hasil internalisasi berbagai kebijakan (virtuse) yang diyakini dan digunakan sebagai landasan cara pandang, berpikir, bersikap, dan bertindak. Selain halhal yang disebutkan di atas, maka perlu disebutkan 5 (lima) pilar karakter yang dipilih oleh banyak sekolah di Amerika Serikat untuk diterapkan dalam pembentukan karakter, yaitu trustworthiness (jujur dan dapat percaya), responsibility (bertanggung jawab), respect (menghormati), fairness (keadilan), dan caring (peduli kepada orang lain). Selain itu, pembentukan karakter dapat dilakukan sejak dini melalui pendidikan. Baik yang diselenggarakan oleh lembaga-lembaga nonformal lainnya, yang diharapkan mampu mencetak generasi yang tangguh serta berkarakter. Dalam kaitannya dengan unsurunsur karakter, kaswan menjabarkan 4 komponen utama, diantaranya: (1) Integritas, (2) Disiplin diri, (3) Nilai-nilai inti, (4) Mentalitas berkelimpahan

Penjelasan kutipan di atas sebagai berikut:

Integritas terdapat dalam orang yang menetapkan sistem norma untuk menilai semua kehidupan. Selain itu, integritas juga merupakan suatu pemenuhan janji yang dibuat 
kepada diri sendiri atau orang lain. Jadi kesimpulan dari kalimat diatas, integritas itu bukan suatu faktor yang ada dengan sendirinya dalam kehidupan setiap orang, melainkan hasil dari keyakinan batin dan sebuah keputusan untuk selalu bersikap jujur dalam kehidupan kita. Integritas juga bukan apa yang kita lakukan.

Disiplin diri, adalah kunci utama menuju keberhasilan salah satunya kunci menuju penghargaan diri, penghormatan diri, dan kebanggan pribadi. Jadi disiplin diri itu tidak mudah dibentuk, namun bukan sesuatu yang mustahil pula. Bahkan disiplin diri kita menjadi kebiasaan, hal itu menjadi mudah dan otomatis. Semakin kita mendisiplinkan diri, semakin besar pula rasa akan penghormatan diri dan kebangggan pribadi.

Nilai-nilai inti, merupakan prinsip yang kita jalani setiap hari dan nilai penting pada titik kesuksesan. Jadi keberhasilan dari tim terdapat pada nilai yang ingin kita inginkan dan kejelasan dari nilainya untuk mencapai suatu tujuan. Mentalitas berkelimpahan, merupakan suatu kepercayaan yang kuat bahwa terdapat sumber daya manusia yang cukup untuk mewujudkan impian kita. Selain itu, mentalitas juga akan menghasilkan tanggung jawab pribadi terhadap kelompok. Dan akan muncul rasa memiliki terhadap kelompoknya.

Selain itu strategi pembentukan karakter adalah suatu keteladanan, pembiasaan, penanaman kedisiplinan, menciptakan suasana yang kondusif, mengembangkan keterampilan dan kebiasaan untuk melindungi keselamatan diri sendiri dan keselamatan orang lain. Setiap orang mempunyai karakter masing-masing, ada yang mempunyai disiplin, jujur, dan karakter egois, orang yang mempunyai karakter egois yang hanya ingin menang sendiri tanpa mementingkan orang lain sulit dalam mencapai suatu tujuan. Lain hal nya dengan orang yang tidak egois, orang yang tidak egois selalu melihat orang sekitar sebagai partnernya dalam mencapai tujuan.

Tidak egois berarti kerjasama, kerjasama adalah sebuah kata yang sangat sering didengar dan sangat akrab di telinga. Kata kerjasama adalah gabungan dari kata kerja dan sama, yang berarti bekerja secara bersama-sama dalam mengerjakan sesuatu dan mencapai suatu tujuan. Kerjasama dibentuk karena adanya dua orang atau lebih yang bekerja bersama untuk mencapai suatu keinginan atau tujuan yang ingin dicapai. Kerjasama didefinisikan sebagai proses sosial melalui performa yang dinilai dan dihargai dengan istilah sekumpulan prestasi dari sekelompok orang yang bekerja sama untuk mencapai tujuan tertenu.

Kerjasama adalah suatu usaha bersama antara orang perorang atau kelompok manusia untuk mencapai satu atau beberapa tujuan bersama. Selain itu, kerjasama juga sebagai suatu usaha antara orang perorang atau kelompok manusia diantara kedua bela pihak untuk tujuan bersama sehingga mendapatkan hasil yang lebih cepat dan lebih baik. Kerjasama dimaksudkan sebagai suatu usaha bersama antara orang perorang atau kelompok manusia untuk mencapai satu atau tujuan bersama.

Dalam hal ini terdapat pengertian lain mengenai kerja sama, bahwa kerja sama merupakan usaha untuk mencapai terget dengan cara bersama-sama. Berikut pengertian kerja sama :

1. Kerjasama sebagai dua orang atau lebih untuk melakukan aktivitas bersama yang dilakukan secara terpadu yang diarahkan kepada suatu target atau tujuan tertentu.

2. Kerjasama adalah suatu strategi bisnis yang dilakukan oleh dua pihak atau lebih dalam jangka waktu tertentu untuk meraih keuntungan bersama dengan prinsip saling membutuhkan dan saling membesarkan.

Penjelasan diatas merupakan pengertian kerjasama dari berbagai para ahli yang pada maknanya memiliki kesamaan pada tercapainya tujuan. Dari pengertian kerjasama diatas, maka ada beberapa aspek yang terkandung dalam hal kerja sama, yaitu: dua orang atau lebih, aktivitas, tujuan/target, dan jangka waktu tertentu. Dibawah penjelasan dari beberapa aspek diatas yaitu sebagai berikut, dua orang atau lebih merupakan 
kerjasama akan ada kalau ada minimal dua orang/pihak yang melakukan kesepakatan. Oleh karena itu, sukses tidaknya kerjasama tersebut ditentukan oleh peran dari kedua orang atau kedua pihak yang bekerja sama tersebut. Aktifitas menunjukan bahwa kerja sama terjadi karena adanya aktivitas yang dikhendaki bersama, sebagai alat untuk mencapai tujuan dan ini membutuhkan strategi (bisnis/usaha). Tujuan/target merupakan aspek yang menjadi sasaran dari kerjasama usaha tersebut, biasanya adalah keuntungan baik secara finansial maupun nonfinansial yang dirasakan atau diterima oleh kedua pihak. Jangka waktu tertentu menunjukan bahwa kerja sama tersebut dibatasi oleh waktu, artinya ada kesepakatan kedua pihak kapan kerjasama itu berakhir. Dalam hal ini, tentu saja setelah tujuan atau target yang dikhendaki telah tercapai.

Bekerja sama dengan orang lain untuk meraih tujuan bersama adalah salah satu pengalaman yang sangat berharga. Kerjasama akan terjalin dengan baik jika ada komunikasi yang baik antar diri endiri dengan diri orang lain.

\section{Sepakbola Usia Dini}

Pada karakteristik tiap kelompok umur terbagi menjadi beberapa bagian sebagai berikut :

\section{JUNIOR E dan F (6-10 tahun)}

Basic training meliputi kelompok usia latihan 6-10 tahun. Pada usia ini, anak-anak biasanya memulai era pendidikan formal dengan bersekolah. Ini berarti secara psikologis anak-anak baru mengenal dunia baru di luar rumah. Secara fisiologis, fundamental gerak motorik biasanya masih kasar dan belum terlatih.

Karakteristik di usia ini adalah era pertumbuhan pesat pertama. Dimana tungkai dan tangan akan bertumbuh menjadi lebih panjang ketimbang batang tubuhnya. Pada saat yang sama organ pada sistem pernapasan jantung semakin membesar ukurannya. Beberapa konsekuensi yang muncul akibat pertumbuhan ini :

1. Banyak bergerak.
2. Semangat berkompetisi tinggi, tidak mau kalah.

3. Koordinasi gerak cenderung kasar.

4. Otot-otot tidak terlatih.

5. Rendahnya tingkat konsentrasi.

6. Sikap sensitive yang dominan.

7. Memiliki idola tokoh dewasa yang jadi panutan.

Awal masa ini juga adalah masa dimana anak-anak memulai sekolah. Dengan lingkungan yang baru di luar rumah, anak berada dalam fase transisi untuk mulai mengenal lingkungan pergaulan di luar rumah. Dalam hal ini, latihan di SSB menjadi lingkungan baru bagi pemain usia ini. SSB akan menjadi tempat yang serupa dengan sekolah, dimana pemain harus belajar bersosialisasi, saling menerima kehadiran teman-temannya.

Tujuan dalam karakteristik pertumbuhan:

1. Menanamkan kecintaan pada olahraga, khususnya sepakbola.

2. Menciptakan lingkungan untuk belajar saling berbagi, saling menerima dan saling menolong. Sehingga anak-anak terbiasa pada lingkungan peprgaulan yang lebih luas.

3. Menyediakan ruang lingkup untuk melatih berbagai gerak atletik dasar. Seperti berjalan, berlari, maju, mundur, berbelok atau melompat. Sehingga anak-anak memiliki koordinasi gerak yang baik.

4. Memperkenalkan beberapa teknik dasar sepakbola secara sederhana. Misal : dribbling, passing, dan shooting.

5. Memperkenalkan konsep dasar sepakbola, yaitu mencetak gol dan mencegah lawan cetak gol.

6. Memperkenalkan beberapa aturan dasar sepakbola. Seperti kickoff, throw in, corner, penalty, goal kick. Juga mengenai pelanggaran dan konsep sportivitas.

\section{JUNIOR D (11-12 tahun)}

Kelompok usia pertama dalam intermediate Training ialah kelompok usia 1112 tahun yang sering disebut dengan Junior D. Rentang usia ini bisa dikatakan merupakan usia emas untuk belajar (Golden age of 
leaning). Beragai materi kepelatihan yang diberkan akan mudah sekali diingat oleh pemain Junior D. Tak salah bila pelatih mulai intens mengajarkan bebagai variasi teknik sepakbola seperti dribbling, control, passing, shooting dan heading di kelompok usia ini.

Karakteristik pertumbuhan di rentang usia ini adalah suatu masa dimana anak-anak mengalami keseimbangan antara pertumbuhan jasmani dengan perekembangan psikologisnya. Itulah sebabnya masa ini sering disebut sebagai "usia harmonis" dan "usia emas untuk belajar." Berikut karakteristik pertumbuhannya:

1. Terjadi perkembangan psikologis yang positif, yakni :

- Percaya diri

- Antusiasme dalam mencari tahu

- Kemauan untuk belajar

- Kemampuan untuk mengobservasi

- Meningkatnya kemampuan berkonsentrasi

- Mulai menyukai persaingan

2. Terjadinya perkembangan fisiologis yang positif , yakni :

- Ukuran tubuh semakin proposional

- Kemampuaan koordinasi yang baik

3. Berbagai situasi di atas membuat anak-anak menjadi lebih siap untuk belajar permainan sepakbola yang lebih spesifik dan kompleks.

Tujuan dalam karakteristik pertumbuhan :

1. Secara sistematis mulai belajar berbagai teknik sepakbola, seperti :

- Variasi dribbling

- Variasi passing

- Variasi ball control

- Variasi shooting

- Variasi heading

(semuanya mampu dilakukan dengan kecepatan dan akurasi di bawah tekanan lawan).

2. Secara sistematis mulai belajar taktik sepakbola sederhana, seperti:

- Running into spaces dengan mengubah arah dan mengubah kecepatan.
- Combination play untuk menguasai possession maupun untuk mencetak gol.

- Secara sistematis mulai melatih kondisi fisik melalui permainan sepakbola itu sendiri.

\section{JUNIOR C (13-14 tahun)}

Kelompok usia berikutnya dalam Intermediate Training 13-14 tahun atau yang populer disebut junior $\mathrm{C}$. Kebalikan dengan Junior D, kelompok Junior C adalah masa usia krisis (age of crisis). Penyebabnya ialah di usia tersebut, anak-anak mengalami pubertas. Saat pubertas, pertumbuhan fisiologi sangat cepat, sehingga pemain sering asing dengan tubuhnya sendiri.

Karakteristik pertumbuhan di usia ini termasuk cepat, dimana tubuh menjadi lebih tinggi dan besar, membuat tubuh tak proposional dan kaku. Oleh karenannya, di masa ini, pemain sulit belajar teknik sepakbola baru. Di sisi lain pemain harus sudah mulai dilatih strenght untuk membiasakan diri dengan tubuhnya yang besar. Berikut karakteristik pertumbuhannya :

1. Rentang usia ini adalah suatu masa dimana anak-anak mengalami pubertas. Ditandai dengan :

- Perkembangan kedewasaan seksual

- Pertumbuhan tubuh yang sangat cepat

2. Secara psikologis pemain cenderung labil, karena merasa asing dengan ukuran tubuhnya byang baru.

3. Secara fisiologis, pertumbuhan tubuh yang sangat cepat menjadi lebih tinggi dan besar secara otomatis menurunkan agility dan koordinasi pemain.

4. Meski masa ini disebut sebagai usia krisis, tetap ada hal positif yang bisa diambil apabila ditangani dengan porsi latihan yang tepat. Misal pemain menjadi lebih kuat, memiliki daya tahan lebih prima dan tentu saja pemahaman akan sepakbola yang lebih baik. 
Tujuan dalam karakteristik pertumbuhan :

1. Memelihara teknik sepakbola yang telah didapat pada Junior C. Secara perlahan mulai ditingkatkan kualitasnya. Misal menjadi lebih cepat, lebih kuat atau lebih akurat.

2. Secara sistematis mulai belajar taktik sepakbola yang lebih kompleks, seperti :

- Use of space

- Position play

- Group defending dan group attacking tactics.

3. Secara sistematis mulai menyiapkan kondisi fisik sepakbola, seperti:

- Coordination, agility dan speed

- Basic stamina

- Basic strength

4. Merangsang kemandirian berpikir dan rasa tanggung jawab.

Sepakbola usia dini mungkin adalah bagian dari sepakbola yang paling banyak disalah pahami. Sponsor, federasi, dan bahkan klub profesional lebih banyak memandangnya sebagai sebuah kewajiban dari pada sebagai sebuah peluang. Tetapi pada kenyataannya, tidak ada jalan pintas untuk dapat membangun sebuah negara sepakbola yang kuat, dan itu semua harus dimulai dari sepakbola level usia dini melalui sekolah sepakbola (SSB)

Era tahun 70 s/d 2000 usia 9 dan 10 th Pernah disebut sebagai usia emas dari perkembangan sepakbola usia dini, sekarang usia 9 dan 10th sudah dinilai terlambat tidak cukup muda untuk memulai latihan, dan sekarang digantikan dengan usia lima dan enam. Halangan terbesar untuk hal ini adalah kebanyakan orang tua tidak percaya bahwa anak-anak semuda itu mampu belajar mengolah bola. Mengolah bola dapat dimulai dari usia yang sangat muda, yaitu empat atau lima tahun.

Satu kesalahan besar dalam melatih anak-anak, yang kebanyakan adalah ketika mereka memberi semangat untuk terus menerus menendang bola. Selain membuat calon pemain itu lelah (belum lagi mengejar bola), kegitan tersebut membuat bosan anakanak bermain bola, terutama dengan ukuran bola orang dewasa, ada baiknya ukuran bola di sesuaikan dengan tingkat umur $4 \mathrm{~s} / \mathrm{d} 8$ th ukuran bola kecil size 3 , atau usia 9 s/d 12 th ukuran size 4 dan usia 13 ke atas ukuran bola dewa size 5 .

Orang tua bisa berperan besar dalam memastikan anak-anak mereka mulai belajar mengolah bola yang tepat. Pemain yang sangat bagus tampak melakukan pendekatan yang alami untuk berlatih, terutama dengan keinginan mereka sendiri. Belajar mengolah bola dari usia muda, empat atau lima tahun, akan membuat potensi mereka mulai berkembang.

Pesepakbola muda membutuhkan banyak pengulangan. Pertama tanpa ada tekanan jadi mereka dapat belajar teknik dan kemudian pada situasi di bawah sedikit atau penuh tekanan. Sebagai contoh pada tournament, kompetisi atau festival sepak bola anak-anak di bawah usia 12 tahun, banyak anak-anak yang di tekankan pada prestasi, harus juara, inilah ambisi seorang pelatih dan orang tua yang salah.

Pada usia ini 7 s/d 12 th di Negara sepakbola maju, semua anak di buat Fun /Senang bermain bola dan di biarkan untuk unjuk skill individu masing-masing pemain, kerjasama antar pemain, bahkan di ajarkan untuk terima kekalahan saat teamnya kalah dan di beri motivasi untuk ke depannya. Kemenangan hanya bonus dari kedisplinan dan rajin latihan. Tidak di tekan untuk menjadi juara di kompetisi/tournament.

Porsi latihan anak-anak untuk usia dini juga sangat di batasi maksimum 288 jam dalam 1 tahun atau 2 jam sehari, atau 6 jam seminggu. Dan dalam 1 bulan minimum di berikan $1 \mathrm{x}$ sparing atau pertandingan persahabatan antar sekolah sepakbola, untuk menilai kemajuan team sekolah bolanya.

Perbedaan pembinaan usia dini di Negara kita dengan Negara-negara berkembang di Eropa dan di Amerika, perbedaan permainan sepakbola usia dini di Indonesia dengan Negara Eropa dan Amerika Latin perbedaan utama permainan sepakbola 
adalah soal kemampuan individu. Bedanya, di Indonesia pemain lewati dua sampai lima pemain sudah dianggap bagus.

Main menang dan dapat piala sudah dianggap bagus. Kalau di Eropa atau amerika latin memang bisa main individu, tapi dibalik itu ada juga permainan kolektivitas yang mereka tunjukan, Sebenarnya, kolektivitas yang lebih penting. Bermain tidak harus ngotot ingin menang, karena nantinya malah berujung ke arah egoisme, menambahkan bahwa dalam sebuah tim sepakbola dibutuhkan kerja sama dari seluruh pihak. Kapan harus menyerang, kapan harus bertahan, kapan kembali ke formasi dan apabila ada kekompakkan dari pemain, pelatih dan staf kepelatihan maka tim tersebut akan dengan mudah terkoordinasi dan dalam sebuah keberhasilan harus ada proses yang berjalan.

Sebuah hasil tim dalam setiap permainan sepakbola pastinya ada proses yang berjalan. Bahkan sebuah tim sepakbola tidak harus memiliki bintang besar untuk menjadi terbaik/juara. Setiap hasil pasti ada prosesnya.

\section{METODE PENELITIAN}

Metode penelitian yang digunakan dalam penelitian ini adalah metode deskriptif dengan teknik survei, yaitu dengan menggunakan kuesioner pembentukan karakter kerjasama.

\section{Populasi dan Sampel}

Populasi dalam penelitian ini adalah orang tua peserta turnamen indonesia junior soccer league berjumlah 1000 orang tua.

Sampel

Teknik pengambilan sampel dalam penelitian ini adalah Sampling Incidental. Sampling Incidental adalah suatu metode dalam meneliti status kelompok manusia, suatu objek, suatu kondisi, suatu system pemikiran, ataupun suatu peristiwa pada masa sekarang. Sampel yang digunakan dalam penelitian ini sebanyak 368 responden.

\section{HASIL PENELITIAN}

Data penelitian yang terdiri dari pengkategorian hubungan pembentukan karakter kerjasama dengan sepakbola usia Dini pada Liga Indonesia Junior Soccer League Berikut ini adalah hasil deskripsi data hasil penelitian:

Tabel 1. Distribusi Frekuensi Hasil Penelitian

\begin{tabular}{|c|c|c|c|c|}
\hline $\begin{array}{l}\mathrm{N} \\
\mathrm{o} \\
\end{array}$ & Kategori & Nilai & $\begin{array}{c}\text { Frekue } \\
\text { nsi }\end{array}$ & $\begin{array}{c}\text { Prosent } \\
\text { ase }\end{array}$ \\
\hline 1 & Rendah & $\begin{array}{c}45- \\
54\end{array}$ & 16 & $4,35 \%$ \\
\hline 2 & Sedang & $\begin{array}{c}55- \\
64 \\
\end{array}$ & 192 & $52,17 \%$ \\
\hline 3 & Tinggi & $\begin{array}{c}65- \\
74 \\
\end{array}$ & 147 & $39,95 \%$ \\
\hline 4 & $\begin{array}{l}\text { Tinggi } \\
\text { sekali }\end{array}$ & $\begin{array}{c}75- \\
84 \\
\end{array}$ & 13 & $3,53 \%$ \\
\hline & Tota & & 368 & $100 \%$ \\
\hline \multicolumn{5}{|c|}{$\begin{array}{c}\text { Frekuensi Hasil } \\
\text { Penelitian }\end{array}$} \\
\hline $\begin{array}{l}300 \\
200\end{array}$ & & & & \\
\hline 100 & & & & \\
\hline 0 & & & & \\
\hline
\end{tabular}

Gambar 1. Diagram Hasil Penelitian

Bagian ini akan menjelaskan lebih lanjut mengenai hasil analisis data yang telah dilakukan serta kaitannya dengan permasalahan dan tujuan penelitian. Tujuan dari penelitian ini adalah untuk mengetahui pembentukan karakter kerjasama melalui sepakbola usia dini pada liga Indonesia Junior Soccer League. Hasil analisis deskriptif menunjukkan bahwa pembentukan karakter kerjasama melalui sepakbola usia dini pada liga Indonesia Junior Soccer League adalah tinggi atau baik. Hal ini terlihat dari hasil analisis data yang menunjukkan bahwa 
mayoritas subjek penelitian yaitu sebanyak 16 orang $(4,35 \%)$ memiliki pengetahuan yang rendah atau buruk terhadap pembentukan karakter kerjasama, sebanyak 192 orang $(52,17 \%)$ memiliki pengetahuan yang sedang atau cukup terhadap pembentukan karakter kerjasama, sebanyak 147 orang $(39,95 \%)$ memiliki pengetahuan yang tinggi atau baik terhadap pembentukan karakter kerjasama dan sebanyak 13 orang $(3,53 \%)$ memiliki pengetahuan yang sangat tinggi atau baik sekali terhadap pembentukan karakter kerjasama.

\section{KESIMPULAN}

Berdasarkan hasil keseluruhan, diketahui bahwa pembentukan karakter kerjasama melalui sepakbola usia dini pada liga Indonesia Junior Soccer League berada pada kategori rendah atau buruk sebanyak 16 orang $(4,35 \%)$ terhadap pembentukan karakter kerjasama, sebanyak 192 orang $(52,17 \%)$ memiliki pengetahuan yang sedang atau cukup terhadap pembentukan karakter kerjasama, sebanyak 147 orang $(39,95 \%)$ memiliki pengetahuan yang tinggi atau baik terhadap pembentukan karakter kerjasama dan sebanyak 13 orang $(3,53 \%)$ memiliki pengetahuan yang sangat tinggi atau baik sekali terhadap pembentukan karakter kerjasama.

\section{SARAN}

Berdasarkan kesimpulan yang telah dipaparkan, maka disampaikan saran-saran sebagai berikut:
1. Mensosialisasikan kepada Sekolah Sepakbola (SSB) bahwa pembentukan karakter kerjasama bias melalui sepakbola.

2. Bagi peserta didik mampu memahami pentingnya pengaplikasian kerjasama dalam sepakbola.

3. Bagi pihak sekolah sepakbola (SSB) agar terus mengembangkan karakter kerjasama peserta didik melalui sepakbola.

\section{DAFTAR PUSTAKA}

Apta Mylsidayu, Psikologi Olahraga. Jakarta: Bumi Aksara, 2015

Ganesha Putera, kutak-katik latihan sepakbola usia muda. Jakarta: PT Visi Gala 2000

http://belajarpsikologi.com/pengertianpendidikan-karakter/ diakses tanngal 09 april 2018

http://file.upi.edu/direktori/FPEB/Prodi.ekono midankoperasi/196302211987032NETIBUDIWATI/membangunkerjasa mausaha.pdf diakses tanggal 11 April 2018

Kaswan, Leadership and Teamworking Bandung: Alfabeta 2013

Mohammad Nazir, Metode Penelitian. Bogor: Ghalia Indonesia, 2005

Soerjono soekanto, Sosiologi Suatu Pengantar. Jakarta; Rajawali 1990

www.journal.uny.ac.id/index.php/jpka/article lunduh/1300/1081 diakses tanggal 09 april 2018 